\title{
SUSTAINABILITY OF GRAPEVINE PRODUCTION THROUGH MORE EFFICIENT SYSTEMS OF SOIL MAINTENANCE AND AGRO-BIOLOGICAL INDICATORS
}

\author{
Alin DOBREI, Faculty of Horticulture and Forestry, Banat`s University of Agricultural Sciences and Veterinary Medicine, Calea \\ Aradului 119, 300 645, Timisoara, Romania, alin1969tmro@yahoo.com (corresponding author) \\ Alina Georgeta DOBREI, Faculty of Horticulture and Forestry, Banat`s University of Agricultural Sciences and Veterinary \\ Medicine, Calea Aradului 119, 300 645, Timisoara, Romania, ghitaalina@yahoo.com \\ Eleonora NISTOR, Faculty of Horticulture and Forestry, Banat`s University of Agricultural Sciences and Veterinary Medicine, \\ Calea Aradului 119, 300 645, Timisoara, Romania, nisnora@ yahoo.com (corresponding author) \\ Sorin STANCIU, Faculty of Agricultural Management, Banat`s University of Agricultural Sciences and Veterinary Medicine, Calea \\ Aradului 119, 300 645, Timisoara, Romania. \\ Mihaela MOATĂR, Faculty of Horticulture and Forestry, Banat`s University of Agricultural Sciences and Veterinary Medicine \\ Calea Aradului 119, 300 645, Timisoara, Romania. \\ Florin SALA, Faculty of Agriculture, Banat`s University of Agricultural Sciences and Veterinary Medicine, Calea Aradului 119, \\ 300 645, Timisoara, Romania.
}

\begin{abstract}
Tillage practices in viticulture are very important, with major effects on quantitative and qualitative production, on vines phenology and stages of growth. In this study the aim was to identify the most appropriate vineyard floor management, located on flat land or mild slopes, with medium or high soils fertility. The research was carried out during 2011-2013 in the vineyard of the BUASVM Didactic Station from Timisoara and focusing exclusively on several variants of soil maintenance in order to replace the need for manual labor. Leaf area was estimated by concentric circles method and sugar concentration was evaluated by refractometry. Total acidity in must and wine was determined by titration. Grape yield was estimated by bunches counting and weighing, for each variety and productive potential $\left(\mathrm{kg} \mathrm{ha}^{-1}\right)$ was appreciated by multiplying the average yield per vine with the number of vines per hectare. Statistical analysis was performed using GraphPad Prism 6. Performance of Burgundy variety for superior red wines group and Silvania table grape variety - with a medium ripening, were analyzed in the experiment. For both Burgundy and Silvania varieties the sixth variant (V6-bare soil by tillage middles row (tractor and rotary hoe)/rotary hoe undervine (tractor and adjustable offset rotary tiller) registered the highest grape yield during the research. The lowest grape yield fulfils to the seventh variant of vineyard floor management. Burgundy variety had the average must sugar content of $195 \pm 4.27 \mathrm{~g} \mathrm{l}^{-1}$ and that of the leaf area of $7.09 \pm 0.58 \mathrm{~m}^{2}$ while in Silvania variety the average of grape must acidity was $4.66 \pm 0.35 \mathrm{~g} \mathrm{l}^{-1} \mathrm{H}_{2} \mathrm{SO}_{4}$ and the leaf area of $7.42 \pm 0.51 \mathrm{~m}^{2} / \mathrm{vine}$. Between must sugar content and leaf area, in Burgundy and Silvania variety has been established a significant positive linear correlation $(\mathrm{r}=0.94 * * *)$ and $(\mathrm{r}=0.88 * * ; \mathrm{p}<0.001)$ respectively, variables being virtually indistinguishable.
\end{abstract}

Keywords: grapevine, leaf area, soil, sugars, sustainability, variety, wine.

\section{INTRODUCTION}

Soil tillage in vineyards is applied differently from one area to another, from one year to another, depending on soil type, climatic conditions, cultivated variety, crop destination and technical equipment of the vineyard holding. Location and floor management are behind the high-quality grapevines. Best locations for a vineyard are those that have well-structured soils with optimum fertility and moisture which provides a favorable environment for vines root system development (Ohmart, 2011). Grape composition and wine quality is the result of interaction of many factors like: maximum wine grape yields and minimum input costs by replacing the manual labor; enhancing grape yield, quality and the net profit; rational use of economic and environmental resources; protection of environment through soil, ecosystem, and biotope conservation and preservation; and, not least the eliminating pollution as much as possible (Martins et al., 2013, Dobrei et al., 2014). Soil biology is represented in the vineyards by the microflora and microfauna (Riches et al., 2013). Anthropic impacts, more and more aggressive grape wine agricultural techniques, lack of organic fertilizers, have led to a biological degradation of the soil. This activity of living organisms in the soil is closely related to the decomposition of the organic matter and not the least to the living component of the soil (Bauer and Black, 1994). Biological potential of the soil can be quantified by the amount of microbiological biomass, by determining enzyme

Copyright (C) 2015 The Authors. Published by Aleksandras Stulginskis University. This is an open-access article distributed under the terms of the Creative Commons Attribution License (CC-BY 4.0), which permits unrestricted use, distribution, and reproduction in any medium, provided the original author and source are credited. 
activity, and analysis of degradation products; biodegradable organic substance was also identified as a major food source for soil microorganisms, of which the balanced edaphic microclimate, identifies with all of the optimal conditions pedological provided (Zarraonaindia et al., 2015).

\section{METHODOLOGY}

Research was carried out during 2011-2013 in the vineyard of the BUASVM Didactic Station from Timisoara and is focusing exclusively on several variants of vineyard floor management in order to replace the need for manual labor. Performance of Burgundy variety for superior red wines group and Silvania table grape variety - with a medium ripening, were analyzed. Observations and measurements performed were: influence of soil maintenance variants on grapes yield; correlations between leaf area and sugar content of the grape must; correlations between leaf area and grape must acidity. The experimental variants consist of different vineyard floor management, as follows: $\mathrm{V}_{1}$ - row middles herbs and grasses strip/bare soil by tillage undervine (tractor and adjustable offset rotary tiller); $\mathrm{V}_{2}$ - bare soil by tillage floor between vines (cultivator)/herbicides treatment undervine; $\mathrm{V}_{3}$ - row middles bare soil by tillage (cultivator)/bare soil by tillage undervine (tractor and adjustable offset rotary tiller); $\mathrm{V}_{4}$ - row middles soil ripping (tractor and ripper)/bare soil by tillage undervine (tractor and adjustable offset rotary tiller); $\mathrm{V}_{5}$ - raw middles herbs and grasses strip/manual hoeing undervine; $\mathrm{V}_{6}-$ bare soil by tillage middles row (tractor and rotary hoe)/rotary hoe undervine (tractor and adjustable offset rotary tiller); $\mathrm{V}_{7}$ - raw middles herbs and grasses strip/herbicides treatment undervine. Leaf area was evaluated based on the average area of a leaf and the average number of leaves on a vine. To calculate leaf area were analyzed 10 vines of each variety. From each vine were: counted the leaves, calculating the average number of leaves, and then were chosen 10 leaves of average size. Leaf area was estimated by concentric circles method. The sugar concentration of the must (in $\mathrm{g} \mathrm{l}^{-1}$ ) was evaluated by refractometry, with Zeiss refractometer. Total acidity in must or wine (as $\mathrm{g} \mathrm{l}^{-1} \mathrm{H}_{2} \mathrm{SO}_{4}$ ), also known as 'titratable acidity', was determined by titration (neutralization) of a sodium hydroxide solution of known normality. Phenolphthalein was used as indicator of acids (colorless). Total acidity was determined by titration using the following formula: acidity $\left(\mathrm{g} \mathrm{l}^{-1} \mathrm{H}_{2} \mathrm{SO}_{4}\right)=\mathrm{n} \times \mathrm{F} \times \mathrm{T} \times 100$; where $\mathrm{n}=\mathrm{ml}$ of $\mathrm{NaOH}$ used for titration; $\mathrm{F}=$ conversion factor of $\mathrm{NaOH}$ solution; $\mathrm{T}=$ titer value for an acid, (for $\mathrm{H}_{2} \mathrm{SO}_{4}$ titer is 0.0049). Grape yield estimation was made at optimal fruit maturity, or ripeness, by bunches counting and weighing, for each variety. Productive potential $\left(\mathrm{kg} \mathrm{ha}^{-1}\right)$ was appreciated by multiplying the average yield per vine with the number of vines per hectare.

\section{RESULTS}

\section{Average yield per vine}

The grape yield is often seen as a quality factor, representing the results of successive stages of vines fruiting. It is often considered as a qualitative factor, lower yields being associated with wines that have a more intense flavor. There is a general consensus that if a large amount of bunches are harvested, poor wine will result because of slow and insufficient ripening, due to an unbalanced relation between leaf area and bunches. For a $200 \mathrm{hl} \mathrm{ha}^{-1}$ yield, wine is poor in the opinion of French wine producers. The same specialists confirmed that is impossible to produce high quality red wines at yields exceeding $50 \mathrm{hl} \mathrm{ha}{ }^{-1}$. Other scientists' opinion is that a grape yield of $100 \mathrm{hl} \mathrm{ha}^{-1}$ combined with optimal management of pruning and training, yielded a high quality wine. Average results obtained during the three years of research on grape production achieved in the Burgundy variety, it is shown in Table 1.

Table 1. Average yield per vine in Burgundy variety during 2011-2013

\begin{tabular}{|c|c|c|c|c|}
\hline No. & Variant & $\begin{array}{c}\text { Yield } \\
\mathrm{kg} / \text { vine }\end{array}$ & $\begin{array}{l}\text { Difference versus } \\
\text { control (kg/vine) }\end{array}$ & Significance \\
\hline 1 & $\begin{array}{l}\mathrm{V}_{1} \text { - row middles herbs and grasses strip, bare soil by tillage undervine } \\
\text { (tractor and adjustable offset rotary tiller) }\end{array}$ & 2.09 & -0.1 & - \\
\hline 2 & $\begin{array}{l}V_{2}-\text { bare soil by tillage floor between vines (cultivator) }+ \text { herbicides } \\
\text { treatment undervine }\end{array}$ & 2.20 & +0.01 & - \\
\hline 3 & $\begin{array}{l}\mathrm{V}_{3}-\text { row middles bare soil by tillage (cultivator) + bare soil by tillage } \\
\text { undervine (tractor and adjustable offset rotary tiller) }\end{array}$ & 2.36 & +0.17 & $* *$ \\
\hline 4 & $\begin{array}{l}\mathrm{V}_{4}-\text { row middles soil ripping (tractor and ripper) + bare soil by tillage } \\
\text { undervine (tractor and adjustable offset rotary tiller) }\end{array}$ & 2.35 & +0.16 & $* *$ \\
\hline 5 & $V_{5}-$ raw middles herbs and grasses strip + manual hoeing undervine & 1.99 & -0.2 & 00 \\
\hline 6 & $\begin{array}{l}\mathrm{V}_{6}-\text { bare soil by tillage middles row (tractor and rotary hoe) + rotary } \\
\text { hoe undervine (tractor and adjustable offset rotary tiller) }\end{array}$ & 2.45 & +0.26 & $* * *$ \\
\hline 7 & $\begin{array}{l}\mathrm{V}_{7} \text { - raw middles herbs and grasses strip }+ \text { herbicides treatment } \\
\text { undervine }\end{array}$ & 1.92 & -0.27 & 000 \\
\hline 8 & Mean (Control) & 2.19 & - & - \\
\hline \multicolumn{5}{|c|}{ DF $0.1 \% \quad 0.25$} \\
\hline
\end{tabular}

$\mathrm{DF}=$ degree of freedom; Mean $=$ average values for Burgundy variety in all experimental variants

Trend of the grapes yield per vine shown by Burgundy variety during research according to the variant of soil management between rows and between vines in row is reflected by the average results. Bare soil by tillage middles row (tractor and rotary hoe)/rotary hoe undervine (tractor and adjustable offset rotary tiller) in V6 was the variant that over the years has given the best results, yields per vine being very higher significant positive $(0.26 \mathrm{~kg})$ compared to control. 
In variants three and four where soil maintenance undervine was made with the tractor and adjustable offset rotary tiller, regardless of soil maintenance between rows either bare soil by tillage (V3) or by ripper (V4) grape yields per vine were distinct significantly higher compared to control. Grass strips between rows and bare soil by tillage undervine in the first experimental variant and herbicides treatment undervine associated with soil tillage between rows with the cultivator, are variants that had grape yields on vine without significant differences compared to the control.

Manual hoeing between vines in row and grass strips alleyways hasn't brought additional production although it required more hand labor. On contrary, it results in distinct significantly lower $(-0.2 \mathrm{~kg})$ grapes yields per vine compared to control. The lowest grapes yields per vine was obtained in each year of research at the variant in which were applied herbicides between vines in row and perennial grass between rows (V7). The difference compared to control has constantly been very significantly lower and negative. In the experimental years (2011-2013) achieved average results are shown in Table 2 . The overall results stands out that the most productive variant was with bare soil by tillage middles row (tractor and rotary hoe)/rotary hoe undervine (tractor and adjustable offset rotary tiller) (V6) which over the years had consistently distinct difference significantly higher compared to control. Row middles bare soil by tillage (cultivator) in V3 and row middles soil ripping (tractor and ripper) in V4 associated with bare soil by tillage undervine (tractor and adjustable offset rotary tiller) were the variants in which the grapes yields per vine was significantly higher than the control. For Silvania variety there were also variants in which grapes yields difference was not significant compared to the control (variants one and two). Lower grapes yields per vine were obtained in variants with grass cover alleyways. In the fifth variant on which was done the manual hoeing undervine, the grapes yield per vine was distinct significantly lower than control (-0.19). In the seventh variant, the grapes yield per vine was even smaller, the difference compared to control being very significantly lower $(-0.31)$.

Table 2. Average grapes yield per vine in Silvania variety (2011-2013)

\begin{tabular}{|c|c|c|c|c|}
\hline No. & Variant & $\begin{array}{c}\text { Yield } \\
\mathrm{kg} / \mathrm{vine}\end{array}$ & $\begin{array}{l}\text { Difference versus } \\
\text { control (kg/vine) }\end{array}$ & Significance \\
\hline 1 & $\begin{array}{l}\mathrm{V}_{1} \text { - row middles herbs and grasses strip, bare soil by tillage undervine } \\
\text { (tractor and adjustable offset rotary tiller) }\end{array}$ & 2.21 & -0.31 & 000 \\
\hline 2 & $\begin{array}{l}\mathrm{V}_{2}-\text { bare soil by tillage floor between vines (cultivator) + herbicides } \\
\text { treatment undervine }\end{array}$ & 2.33 & +0.03 & - \\
\hline 3 & $\begin{array}{l}\mathrm{V}_{3}-\text { row middles bare soil by tillage (cultivator) + bare soil by tillage } \\
\text { undervine (tractor and adjustable offset rotary tiller) }\end{array}$ & 2.46 & +0.16 & * \\
\hline 4 & $\begin{array}{l}\mathrm{V}_{4} \text { - row middles soil ripping (tractor and ripper) + bare soil by tillage } \\
\text { undervine (tractor and adjustable offset rotary tiller) }\end{array}$ & 2.47 & +0.17 & $*$ \\
\hline 5 & $\mathrm{~V}_{5}$ - raw middles herbs and grasses strip + manual hoeing undervine & 2.11 & -0.19 & 00 \\
\hline 6 & $\begin{array}{l}\mathrm{V}_{6} \text { - bare soil by tillage middles row (tractor and rotary hoe) + rotary } \\
\text { hoe undervine (tractor and adjustable offset rotary tiller) }\end{array}$ & 2.54 & +0.24 & $* *$ \\
\hline 7 & $\begin{array}{l}\mathrm{V}_{7}-\text { raw middles herbs and grasses strip }+ \text { herbicides treatment } \\
\text { undervine }\end{array}$ & 1.99 & -0.31 & 000 \\
\hline 8 & Mean (Control) & 2.30 & - & - \\
\hline \multicolumn{5}{|c|}{ DF $0.1 \% \quad 0.29$} \\
\hline
\end{tabular}

$\mathrm{DF}=$ degree of freedom; Mean = average values for Silvania variety in all experimental variants

Grapes yields in Silvania variety were much lower in all variants than those reported by Smart et al. (1990) of $3.8 \mathrm{~kg}$ per vine in Cabernet franc or those obtained by Todic (2004) in Limberger variety between 4.89 and $5.84 \mathrm{~kg}$ per vine. Instead Sivčev et al. (2005) reported in Riesling variety a grape yield/vine close to that of Silvania variety - between 2.04 and $2.63 \mathrm{~kg} / \mathrm{vine}$. Opinions on different vineyards floor management are divided. Some researches has proved that cover grass alleyways are leading to production cuts as results obtained in Chenin blanc by Van Huyssteen and Weber (1980) on a medium texture soil confirmed. The use of cover crops and natural vegetation between rows of vines is considered to decrease the vigor of the vine (Pool et al., 1990). These perennial crops, according to Pinamonti et al. (1996) statements, lead to a significant decrease of nitrogen concentration in young leaves, but at the same time to an increased amount of $\mathrm{P}$ and $\mathrm{K}$, compared to soil maintenance with chemical control of weeds or bare soil (Sicher et al., 1995). Buckerfield and Webster (1996) noted that when straw mulch between rows and herbicides treatments undervine is used, grapes yields is significantly higher than bare soil practice.

\section{Correlations concerning the leaf area and must sugar content}

Sugar content of grapes, must and wine is an important parameter for viticulturists, whereas alongside acidity is probably the most important parameter in winemaking (oenology). The amount of sugars is important to appreciate: the optimal time to harvest grapes for wine or table, but also to establish the strategy for winemaking (obtaining dry, halfsweet, sweet wines, etc.). Sugars are important, because after fermentation results alcohol (at a sugar content of $17 \mathrm{~g} \mathrm{l}^{-1}$ is obtained about $10^{\circ}$ alcohol). Sugars named also glucides, saccharides or carbohydrates are organic plants compounds, resulting from $\mathrm{CO}_{2}$ and $\mathrm{H}_{2} \mathrm{O}$ in photosynthesis process. The must resulted from grapes usually contains $150-250 \mathrm{~g} \mathrm{l}^{-1}$ sugars, amount different for each variety, vineyard, weather conditions, ripeness and crop health. When wine is made of overripe, dried or affected by noble rot grapes, the sugar content can reach 250-350 $\mathrm{g} \mathrm{l}^{-1}$. For an ordinary wine it's not necessary more than 170-180 $\mathrm{g} \mathrm{l}^{-1}$ sugars. Grape must sugar content and leaf area for Bugundy and Silvania varieties are illustrated in Figure 1 and Figure 2. In studied varieties grape sugar content is situated among $189-200 \mathrm{~g} \mathrm{l}^{-1}$ in 
Burgundy and respectively $165.3-180 \mathrm{~g} \mathrm{l}^{-1}$ in Silvania variety. In both cases the smaller content is associated with the less leaf area and the highest content of sugar with the largest leaf area.

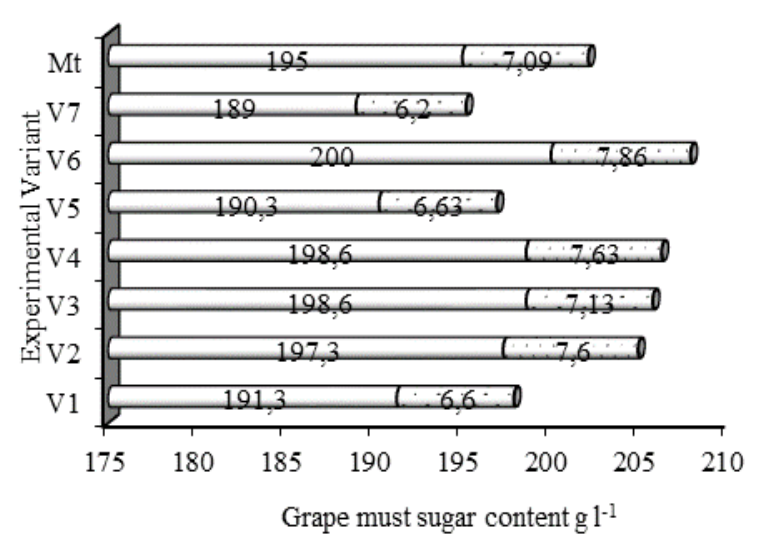

Figure 1. Grape must sugar content $\left(\mathrm{g}^{-1}\right)$ and leaf area $\left(\mathrm{m}^{2} /\right.$ vine) in Burgundy variety during 2011-2013

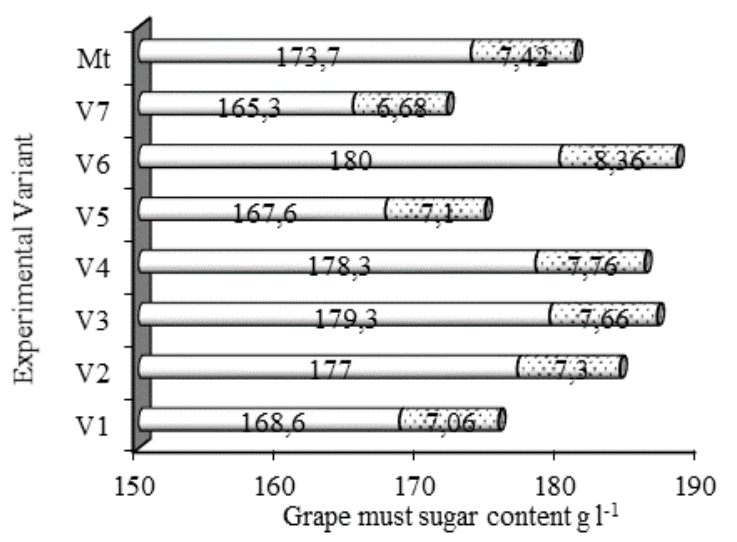

Figure 2. Grape must sugar content $\left(\mathrm{g} \mathrm{l}^{-1}\right)$ and leaf area $\left(\mathrm{m}^{2} / \mathrm{vine}\right)$ in Silvania variety during 2011-2013

In the grapes and must are found sugars from all groups, but dominant are monosaccharide (pentoses, hexoses). Thus, glucose and fructose (in almost equal proportion to full ripeness) represents over $95 \%$ of total sugars in the must. In addition galactose (100-150 $\mathrm{mg} \mathrm{l}^{-1}$ ) may be present in berries or must. Pentoses (arabinoses, xyloses, riboses, ramnoses) are found in much smaller amounts than hexoses, $1-2 \mathrm{~g} \mathrm{l}^{-1}$ respectively.

Statistical analysis was performed using GraphPad Prism 6. Overall during research, in Burgundy, the average must sugar concentration was $195 \pm 4.27 \mathrm{~g} \mathrm{l}^{-1}$ and for leaf area of $7.09 \pm 0.58 \mathrm{~m}^{2}$. In both variables, the amplitude of variation is reduced. The coefficient of variation values $(\mathrm{CV}=2.19 \%$ for the must sugar content and $\mathrm{CV}=8.24 \%$ for leaf area) indicates a very high homogeneity, the average being representative for both variables as shown in table below (Table 3).

Table 3. Parameters of leaf area ( $\mathrm{m}^{2} /$ vine $)$ and must sugar content $\left(\mathrm{g} \mathrm{l}^{-1}\right)$, at Burgundy variety during 2011-2013

\begin{tabular}{|l|c|c|c|c|c|c|c|c|c|}
\hline & $\mathrm{N}$ & Mean & Min-Max & $\begin{array}{c}\text { Standard } \\
\text { deviation }\end{array}$ & $\begin{array}{c}\text { Standard } \\
\text { Error }\end{array}$ & $\begin{array}{c}\text { Coef. } \\
\text { var. \% }\end{array}$ & C.I./95 \% & $\mathrm{r}$ & $\mathrm{r}^{2}$ \\
\cline { 1 - 9 } & 8 & 195 & $189-200$ & 4.27 & 1.51 & 2.19 & $191.4-198.6$ & \multirow{2}{*}{0.94} & 0.88 \\
\hline Leaf area $\left(\mathrm{m}^{2}\right)$ & 8 & 7.09 & $6.2-7.8$ & 0.58 & 0.20 & 8.24 & $6.6 .-7.58$ & 0.94 \\
\hline
\end{tabular}

In Burgundy variety during 2011-2013, between must sugar content and leaf area, it was a very strong and positive linear correlation $(\mathrm{r}=0.94 * * *)$, the variables being virtually indistinguishable $(\mathrm{p}<0.0001)$.

In a very high rate $\left(r^{2}=0.88\right)$, the must sugar content is dependent of leaf area per vine. The average results obtained during research for the must sugar content and leaf area in Silvania variety is shown in Figure 2.

The sixth variant remains in all experimental years with the best results. Grassing alleyways and herbicides treatment applied undervine was in Silvania variety the variant with the worst results, because species of perennial grass competing with vine for nutrients and water from the soil, and furthermore contributes to the vine shading at the bottom of the bunch.

Table 4. Parameters of leaf area ( $\left.\mathrm{m}^{2} / \mathrm{vine}\right)$ and must sugar content $\left(\mathrm{g}^{-1}\right)$ at Silvania variety during 2011-2013

\begin{tabular}{|l|c|c|c|c|c|c|c|c|c|}
\hline & $\mathrm{N}$ & Mean & Min-Max & $\begin{array}{c}\text { Standard } \\
\text { deviation }\end{array}$ & $\begin{array}{c}\text { Standard } \\
\text { Error }\end{array}$ & $\begin{array}{c}\text { Coef. } \\
\text { var.\% }\end{array}$ & C.I./95 \% & $\mathrm{r}$ & $\mathrm{r}^{2}$ \\
\cline { 1 - 9 } & 8 & 173.7 & $165.3-180.0$ & 5.81 & 2.05 & 3.35 & $168.9-178.6$ & \multirow{2}{*}{0.88} & 0.77 \\
\hline Lust sugar content $\left(\mathrm{g} \mathrm{l}^{-1}\right)$ & 8 & 7.41 & $6.6 .-8.3$ & 0.51 & 0.18 & 6.93 & $6.98-7.87$ & 0.88 \\
\hline
\end{tabular}

The average concentration of sugar in grape berries of Silvania variety $\left(172.7 \pm 5.81 \mathrm{~g} \mathrm{l}^{-1}\right)$ and leaf area/vine $\left(7.41 \pm 0.51 \mathrm{~m}^{2}\right)$ is representative and in range of confidence interval $(\mathrm{CI}=95 \%)$ (Table 4). Values for must sugar content were lower than those founded by Hilbert et al. (2003) in Merlot from 2001 crop, which had an amplitude of variation between $206.7 \pm 2.5$ to $240.7 \pm 2.8 \mathrm{~g} \mathrm{l}^{-1}$.

For both parameters all values are spread very close to the mean, as coefficient of variation shown. Between the must sugar concentration and leaf area per vine in Silvania variety, during the research has been established a distinct significant positive linear correlation $(\mathrm{r}=0.88 * * ; \mathrm{p}<0.001)$.

Must sugar content can be directly influenced by the content of total anthocyanins and closely linked to peonidin derivatives (primary pigment of the shell responsible for the red-purple color). Anthocyanidins are highly conjugate chromophore and are therefore influenced by $\mathrm{pH}$ (He et al., 2012). 
When the $\mathrm{pH}$ is changed, the degree of conjugation (double bonds) is modified, and in the same time is changed the wavelength of the light, and that of the energy absorbed at the molecular level. Natural anthocyanidins are generally most stable in an environment with a very low pH. At $\mathrm{pH}$ of 8.0 for the most part become colorless (He et al., 2012).

However, unlike many anthocyanidins, it is stable at a higher $\mathrm{pH}$. At $\mathrm{pH} 2.0$, peonidin is purple, pink strong yellowish to 3.0, over pH 5.0 the grapes are red-purple, and become blue at pH 8.0. This anthocyanin is found in black

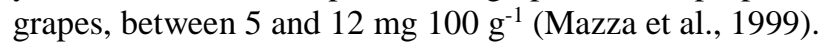

\section{Correlations concerning the leaf area and must acidity}

The total acidity of the must or wine is given by the sum of the concentration of all the acid cations of the free half-bonded acids and which may be titrated when the $\mathrm{pH}$ value was adjusted to seven by the addition of an alkaline solution titrated. In the total acidity is not including the carbon dioxide and the free and combined sulfur dioxide.

The total acidity of grape must is given by specific non-volatile organic acids, and this measure is called the titratable acidity. Existing organic acids (polycarboxylic acid, tartaric acid, malic acid, citric acid, and oxalic acid) are free or partially bonded in the form of acid salts.

Conventionally, the acidity of grape must and wines can be expressed in $\mathrm{g} \mathrm{l}^{-1}$ tartaric acid or in $\mathrm{g} \mathrm{l}^{-1}$ sulfuric acid or milligrams per liter $\left(\mathrm{mEq} \mathrm{l}^{-1}\right)$, (Boulton, 1980). In accordance with the Implementing Regulations of Vine and Wine Law no. 67/1997, the total acidity of the wine must be between: from 4.5 to $9 \mathrm{~g} \mathrm{l}^{-1}$ tartaric acid, $3-6 \mathrm{~g} \mathrm{l}^{-1}$ sulfuric acid and $60-120 \mathrm{mEq} \mathrm{l}^{-1}$. For a more obvious conclusion of the results obtained over the years, the average values are illustrated for both studied variables in the figures below (Figure 3).

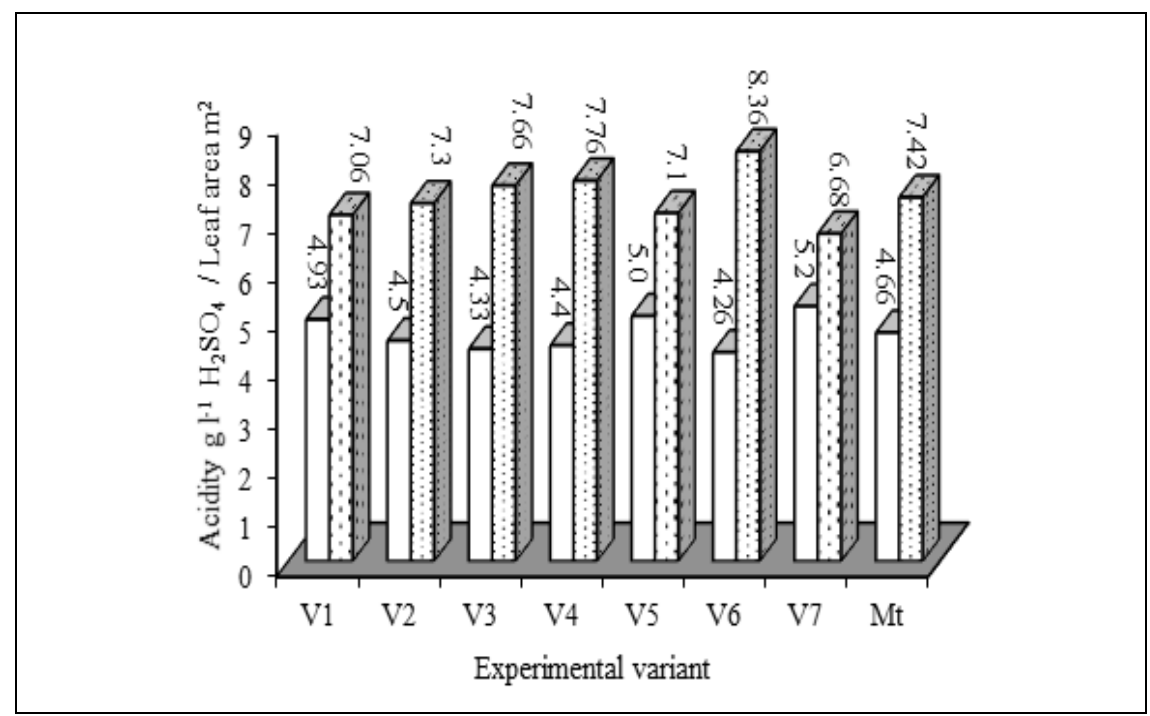

Figure 3. Grape must acidity $\left(\mathrm{g} \mathrm{l}^{-1}\right) \mathrm{H}_{2} \mathrm{SO}_{4}$ and leaf area ( $\mathrm{m}^{2} /$ vine) in Burgundy variety during 2011-2013

Columns from the diagram show that the amplitude variability of grape must acidity and leaf area in Burgundy variety is minimal. The coefficient of variation values confirming this presentation.

Table. 5. Parameters of leaf area ( $\left.\mathrm{m}^{2} / \mathrm{vine}\right)$ and must acidity $\left(\mathrm{g} \mathrm{l}^{-1} \mathrm{H}_{2} \mathrm{SO}_{4}\right)$ at Burgundy variety during 2011-2013

\begin{tabular}{|c|c|c|c|c|c|c|c|c|c|}
\hline & $\mathrm{N}$ & Mean & Min-Max & $\begin{array}{l}\text { Standard } \\
\text { deviation }\end{array}$ & $\begin{array}{c}\text { Standard } \\
\text { Error }\end{array}$ & $\begin{array}{l}\text { Coef. } \\
\text { var. \% }\end{array}$ & C.I./95\% & $\mathrm{r}$ & $\mathrm{r}^{2}$ \\
\hline Grape must acidity $\left(\mathrm{g} \mathrm{l}^{-1}\right) \mathrm{H}_{2} \mathrm{SO}_{4}$ & 8 & 5.31 & $5.1-5.7$ & 0.23 & 0.08 & 4.32 & $5.12-5.50$ & \multirow[b]{2}{*}{-0.92} & \multirow[b]{2}{*}{0.85} \\
\hline Leaf area $\left(\mathrm{m}^{2}\right)$ & 8 & 7.09 & $6.2-7.8$ & 0.58 & 0.20 & 8.24 & $6.6-7.58$ & & \\
\hline
\end{tabular}
$\mathrm{p}<0.001^{* *}$

The average must grape acidity during research years was $5.31 \pm 0.23 \mathrm{~g} \mathrm{l}^{-1} \mathrm{H}_{2} \mathrm{SO}_{4}$ and for the leaf area/vine $7.09 \pm 0.58 \mathrm{~m}^{2}$, values which are representative for the limits of the confidence interval $(\mathrm{CI}=95 \%)$. In all years, leaf area was the most important element in determining the grape must acidity as coefficient of determination $\left(r^{2}=0.85\right)$ shows (Table 5). This determination is supported by the distinct and significantly negative linear correlation $(r=-0.92)$, which has been established between the grape must acidity of Burgundy grape variety and leaf area per vine. The values obtained are plotted in the figure below (Figure 4). 


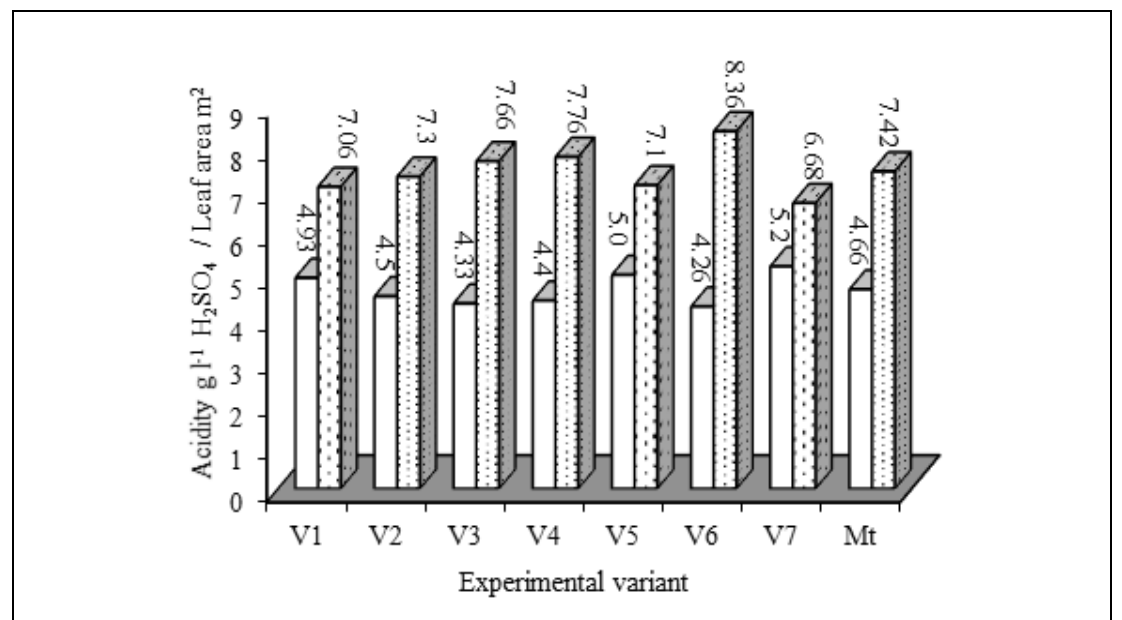

Figure 4. Grape must acidity $\left(\mathrm{g} \mathrm{l}^{-1}\right) \mathrm{H}_{2} \mathrm{SO}_{4}$ and leaf area (m²/vine) in Silvania variety during 2011-2013

The must acidity in Silvania variety is situated between 4.26 and $5.2 \mathrm{~g} \mathrm{l}^{-1}$. As figure 4 shows there is a negative association between must acidity and leaf area. The highest acidity is registered in the variant with the largest leaf area.

Table. 6. Parameters of leaf area ( $\left.\mathrm{m}^{2} / \mathrm{hub}\right)$ and must acidity $\left(\mathrm{g} \mathrm{l}^{-1} \mathrm{H}_{2} \mathrm{SO}_{4}\right)$ at Silvania variety during 2011-2013

\begin{tabular}{|l|c|c|c|c|c|c|c|c|c|}
\hline & $\mathrm{N}$ & Mean & Min-Max & $\begin{array}{c}\text { Standard } \\
\text { deviation }\end{array}$ & $\begin{array}{c}\text { Standard } \\
\text { Error }\end{array}$ & $\begin{array}{c}\text { Coef } \\
\text { var. \% }\end{array}$ & $\begin{array}{c}\text { C.I. } \\
95 \%\end{array}$ & $\begin{array}{c}\mathrm{r} \\
\mathrm{r}^{2}\end{array}$ \\
\hline Grape must acidity $\left(\mathrm{g} \mathrm{l}^{-1}\right) \mathrm{H}_{2} \mathrm{SO}_{4}$ & 8 & 4.66 & $4.26-5.2$ & 0.35 & 0.12 & 7.44 & $4.37-4.95$ & - & \multirow{2}{*}{0.81} \\
\hline Leaf area $\left(\mathrm{m}^{2}\right)$ & 8 & 7.42 & $6.68-8.36$ & 0.51 & 0.18 & 6.93 & $6.98-7.85$ & 0.90 & 0.81 \\
\hline
\end{tabular}

For all experimental years, in Silvania variety (Table 6), the average grape must acidity was $4.66 \pm 0.35 \mathrm{~g} \mathrm{l}^{-1}$ $\mathrm{H}_{2} \mathrm{SO}_{4}$ while the average leaf area was of $7.42 \pm 0.51 \mathrm{~m}^{2} /$ vine. These values are situated within the limits of the confidence interval $(\mathrm{CI}=95 \%)$. The coefficient of variation confirms that the scattering of data is very small and the average is representative because the analyzed data are homogeneous. Distinct and significantly negative linear correlation $(\mathrm{r}=-0.90 * *)$ indicates that excess canopy results in increased grape must level acidity $(\mathrm{p}<0.001)$.

It is demonstrated by numerous studies that the increasing of leaf area is leading to the thickening of cover crops, resulting in decreased accumulation of sugars and in the same time to the increased total acidity of the must (Fuentes et al., 2014). Concerning the extreme weather phenomena in 2013 was better for viticulture compared to 2012 when the vines were affected by sudden frosts in February and then by stronger atmospheric and soil drought from June to August.

\section{CONCLUSIONS}

Mechanization of vineyards is an essential condition for the success of this crop due to the lack and high cost of manual labor and in short time intervals to carry out certain works. Burgundy variety yield, in all the years has shown a highly significant superior production compared to the control, variant (V6). The V7 variant in Burgundy variety had the lowest grapes yields, the difference from the control being very significant negative. In Silvania variety, a very significantly higher yield compared to the control was obtained in variant V6.

The leaf area per vine and per vineyard (ha) can have both positive and negative influence. The buds that develop on the strings with a large leaf area, which gets less light, will develop fewer flowers than those found on the strings with an optimum number of leaves. A reduced leaf area allows at the same time better airflow, faster drying of leaves and easier application of treatments during the growing season, and thus is reduced the frequency of diseases.

The coefficient of variation values indicates a very high homogeneity. Between the must sugar content and leaf area per vine for Silvania variety during the research has been established a distinct and significant positive linear correlation $(r=0.88)$. Leaf area was during the three experimental years the most important factor in determining the must acidity as evidenced by the coefficient of determination. This determination is supported by the distinct significantly negative linear correlation, which has been established between the acidity of Burgundy grape variety and leaf area per vine $(r=-0.92)$. Values for Silvania variety grape must acidity and the leaf area are within the limits of the confidence interval. The coefficient of variation confirms that the scattering of data is very small and the average is representative since analyzed data are homogeneous. Distinct and significantly negative linear correlation shows that excess canopy results in increased must level acidity. Results for the two varieties emphasize that Silvania (table variety) had a larger leaf area and a higher yield of grapes per vine and must acidity while Burgund (wine variety) has a higher content of sugar amid a less leaf area. In studied vineyard, for both grape varieties the best results were obtained in the experimental variant with bare soil between rows and undervine floor management. 


\section{REFERENCES}

1. Bauer, A., Black, A. L. 1994. Quantification of the effect of soil organic matter content on soil productivity. Soil Science Society of America Journal, Vol. 58, Iss. 1, pp. 185-193. http://dx.doi.org/10.2136/sssaj1994.03615995005800010027x

2. Boulton, R. 1980. The Relationships between total acidity, titratable acidity and $\mathrm{pH}$ in wine. American Journal of Enology and Viticulture, Vol. 31, pp. 76-80.

3. Buckerfield, J. C., Webster, K. A. 1996. Earthworms, mulching, soil moisture and grape yields. Wine Industry Jobs, Vol. 11, pp. 47-53.

4. Dobrei, A., Dobrei, A. G., Sala, F., Nistor, E., Mălăescu, M., Dragunescu, A., Cristea, T. 2014. Research concerning the influence of soil maintenance on financial performance of vineyards. Journal of Horticulture, Forestry and Biotechnology, Vol. 18, Iss. 1, pp. 156-164.

5. Fuentes, S., Poblete-Echeverría, C., Ortega-Farias, S., Tyerman, S., De Bei, R. 2014. Automated estimation of leaf area index from grapevine canopies using cover photography, video and computational analysis methods. Australian Society of Viticulture and Oenology Inc., Vol. 20, Iss. 3, pp. 465-473. http://dx.doi.org/10.1111/ajgw.12098

6. He, F., Liang, N-N., Lin, M., Qiu-Hong, P., Jun, W., Reeves, M.J., Chang-Qing, D. 2012. Anthocyanins and their variation in red wines II. Anthocyanin derived pigments and their color evolution. Molecules 2012, Vol. 17 Iss. 2, pp. $1483-1519$. http://dx.doi.org/10.3390/molecules17021483

7. Hilbert, G., Soyer, J. P., Molot, C., Giraudon, J., Milin, S., Gaudillere, J. P. 2003. Effects of nitrogen supply on must quality and anthocyanin accumulation in berries of cv. Merlot. Vitis, Vol. 42, No. 2, pp. 69-76.

8. Mazza, G., Fukumoto, L., Delaquis, P., Girard, B., Ewert, B. 1999. Anthocyanins, phenolics, and color of Cabernet Franc, Merlot, and Pinot Noir wines from British Columbia. Journal of Agricultural and Food Chemistry, Vol. 47, pp. $4009-4017$. http://dx.doi.org/10.1021/jf990449f

9. Martins, G., Lauga, B., Miot-Sertier, C., Mercier, A., Lonvaud, A., Soulas, M.-L., Soulas, G., Masneuf-Pomarède, I. 2013. Characterization of epiphytic bacterial communities from grapes, leaves, bark and soil of grapevine plants grown, and their relations, PLOS ONE, Vol. 8, Iss. 8, e73013. http://dx.doi.org/10.1371/journal.pone.0073013

10. Ohmart, C. P. 2011. View from the Vineyard: A Practical Guide to Sustainable Winegrape Growing. Wine Appreciation Guild. p. 219.

11. Pinamonti, F., Stefanini, M., Dalpiaz, A. 1996.Soil management effects on nutritional status and grapevine performance. WeinWissen, Vol. 51, pp. 76-82.

12. Pool, R. M., Dunst, R. M., Lakso, A. N. 1990. Comparison of sod, mulch, cultivation, and herbicide floor management practices for grape production in nonirrigated vineyards. Journal of the American Society for Horticultural Science, Vol. 115, Iss. 6, pp. $872-877$.

13. Regulations of Vine and Wine Law no. 67/1997, Romania, Of. M.no. 81/5 May 1997.

14. Riches, D., Porter, I. J., Oliver, D. P., Bramley, R. G. V., Rawnsley, B., Edwards, J., White, R. E. 2013. Review: soil biological properties as indicators of soil quality in Australian viticulture. Biological indicators for soil quality. Australian Journal of Grape and Wine Research, Vol. 19, Iss. 3, pp. 311-323. http://dx.doi.org/10.1111/ajgw.12034

15. Sivčev, B., Jović, S., Raičević, V., Petrović, A., Lalević, B. 2005. Application of microbiological fertilizers in viticulture: grape yield and quality of wine cv. Riesling. Journal of Agricultural Sciences, Vol. 50, No 1, pp. 19-26.

16. Sicher, L., Dorigoni, A., Stringari, G., 1995. Soil management effects on nutritional status and grapevine performance. Acta Horticulturae, Vol. 383, pp.73-82. http://dx.doi.org/10.17660/ActaHortic.1995.383.8

17. Smart, R. E., Dick, J. K., Gravett, I. M., Fisher, B. M. 1990. Canopy management to improve grape yield and wine quality principles and practices. South African Journal for Enology and Viticulture, Vol. 11, pp.3-17.

18. Todic, S. R. 2004. Grape yield and quality of the grapevine cultivar Limberger treated with plant growth regulators. Journal of Agricultural Sciences, Vol. 49, No. 2, UDC: 634.84:631.811.98, pp. 141-147.

19. Van Huyssteen, L., Weber, H. W. 1980. The effect of selected minimum and conventional tillage practices in vineyard cultivation on vine performance. South African Journal for Enology and Viticulture, Vol. 1, pp. 77-83.

20. Zarraonaindia, I., Owens, S. M., Weisenhorn, P., West, K., Hampton-Marcell, J., Lax, S., Bokulich, N. A., Mills, D. A., Martin, G., Taghavi, S., Van Der Lelie, D., Gilbert, J. A. 2015. The Soil Microbiome Influences Grapevine-Associated Microbiota. American Society for Microbiology,Vol. 6, Iss. 2, e02527-14, http://dx.doi.org/10.1128/mBio.02527-14 